\title{
Predestinasi
}

Volume 13, No. 1, Juni 2020, Hal. 1 - 6

ISSN (Print): 1978-9351

\section{Perempuan Pengrajin Gerabah di Desa Wanio Kecamatan Pancalautang Kabupaten Sidenreng Rappang}

\author{
Syamsiah $^{1 *}$, Firdaus W.Suhaeb ${ }^{2}$ \\ ${ }^{1}$ Sosiologi/ Universitas Negeri Makassar \\ Email:syamsiah@yahoo.com \\ ${ }^{2}$ Dosen Sosiologi/ Universitas Negeri Makkassar \\ Email:firdaus.suhaeb@unm.ac.id
}

\begin{abstract}
ABSTRAK
Penelitian ini bertujuan menggambarkan kondisi perempuan yang bekerja sebagai pengrajin gerabah. Jenis penelitian ini yaitu deskriptif kualitatif. Metode pengumpulan data dalam penelitian ini yaitu melalui wawancara, obsevasi, dan dokumentasi. Sasaran enelitian ini adalah perempuan pengrajin gerabah di Desa Wanio kec. Pancalautang Kab. Sidrap yang kemudian dipilih 7 orang yang menjadi informan penelitian melalui teknik purposive sampling, dengan kriteria yaitu perempuan pengrajin gerabah yang sudah berkeluarga, sebagai pengrajin gerabah dan lama/ tidaknya menekuni pekerjaan sebagai pengrajin gerabah. Hasil penelitian menunjukkan Profil kehidupan perempuan pengrajin gerabah yang pertama dilihat dari aspek pendidikan, kedua aspek kesehatan dan ketiga aspek pendapatan. Perempuan pengrajin gerabah membagi dua waktu dalam menjalankan dua ranah sekaligus yaitu langsung membuat gerabah dan ada juga yang menyelesaikan pekerjaan dirumah sebelum membuat gerabah. Dampak positif yang dirasakan perempuan dalam membuat gerabah yaitu dapat membantu perekonomian keluarga selain itu dapat meningkatkan rasa harga diri, kepuasan hidup dan kesehatan terjaga. Adapun dampak negatif yaitu kurangnya waktu bersama keluarga, dan beban kerja
\end{abstract}

Kata Kunci: Perempuan, Kerajinan Gerabah, pengrajin

\begin{abstract}
This study aims to describe the condition of women who work as pottery craftsmen. This type of research is descriptive qualitative. Data collection methods in this study are through interviews, observation, and documentation. The target of this research is women craftsmen of pottery in the village of Wanio, kec. Pancalautang Kab. Sidrap then selected 7 people who became research informants through a purposive sampling technique, with the criteria being women pottery craftsmen who are married, as pottery craftsmen and whether or not they have been working as pottery craftsmen for a long time. The results showed the profile of the life of the first pottery craftsman from the education aspect, the second the health aspect and the third the income aspect. The woman who craftsmen divides her time in carrying out the two domains at
\end{abstract}


once, namely directly making pottery and there are also those who finish work at home before making pottery. The positive impact felt by women in making pottery is that it can help the family economy besides that it can increase a sense of self-esteem, life satisfaction and health is maintained. The negative impacts are lack of time with family and workload.

Keywords: Women; Pottery Crafts; craftsmen

\section{PENDAHULUAN}

Kedudukan dan peran perempuan yang ikut terlibat di ranah domestik dan juga ranah publik, terkadang tidak diperhatikan dikeluarga maupun masyarakat, karena tidak adanya kesetaraan gender (Abu Bakar et al., 2017; Adil \& Kamal, 2016; Daraba et al., 2018; Turan \& Kara, 2018). Gender lebih dimaknai sebagai suatu kesetaraan, yaitu sebagai sebuah prospek kesetaraan antara pria dan wanita untuk tidak diskriminasi di dalam ketidaksetaraaan struktur dan fungsi untuk mengakses sumber daya, kesempatan, dan jasa. Kesetaraan gender ini membawa pria dan perempuan sebagai pasangan yang saling membangun dan saling menopang untuk mencapai sebuah tujuan. Berarti pria dan perempuan memiliki kesetaraan yang mengakui bahwa setiap orang bisa terlibat dalam aspek kehidupan sosial, budaya, ekonomi, pemerintahan, dan politik melalui kesetaraan gender (Davis \& Williamson, 2019; Zhang \& Zhang, 2020).

Peran ganda perempuan yaitu peran perempuan yang telah berumah tangga dalam kehidupan sosial juga berarati keterlibatan mengambil keputusan dalam melaksanakan tugastugas rumah tangga dan tugas pekerjaan diluar rumah dalam mencapai tujuan tertentu sesuai kemampuan, status dan tanggungjawabnya (Johnson et al., 2020; Rohlinger et al., 2020). Seperti halnya di desa Wanio,Sidrap, perempuan yang telah berumah tangga ikut bekerjadisamping perannya sebagai ibu rumah tangga yang mengurus rumah, suami dan anak mereka juga bekerja diluar rumah. Ada yang bekerja sebagai guru, pegawai kantoran, membantu suami di kebun ada yang juga yang membuat gerabah. Pekerjaan membuat gerabah inilah yang banyak mendominasi ibu-ibu rumah tangga di desa Wanio.

Gerabah yang mereka buat bahannya dari tanah liat dan cara membuatnya masih dengan cara tradisional. Bentuk-bentuk dari gerabah bermacam-macam sesuai dengan fungsinya. Wanita pengrajin gerabah di desa Wanio, Sidrap ini menginspirasi saya untuk melakukan penelitian seputar perannya sebagai ibu rumah tangga yang bekerja diluar rumah. Dalam menjalankan peran ganda, perempuan dihadapkan oleh dampak yang akan ditimbulkan yang mungkin berpengaruh terhadap kehidupan keluarga, begitu pula dengan ibu rumah tangga yang ada di desa Wanio, Sidrap akan dihadapkan dengan adanya dampak dari pekerjaan mereka sebagai pengrajin gerabah. Yang menarik, dari permasalahan ini yaitu walaupun ibu rumah tangga yang kodratnya di rumah, namun mereka mampu bertahan dengan pekerjaan mereka di luar rumah, karena tidak mudah untuk menjalankan peran ganda.

\section{METODE}

Dalam penelitian ini menggunakan pendekatan penelitian deskriptif (descriptive research) yaitu suatu jenis penelitian yang berusaha mendapatkan pengetahuan yang dasarnya pada data-data empiris (Creswell \& Creswell, 2017; Rukajat, 2018). Lokasi pelaksanaan penelitian mengenai perempuan pengrajin gerabah ini yaitu di desa Wanio kabupaten Sidrap. Memilih lokasi ini karena alasan di desa Wanio ini dominan pekerjaan perempuan. Teknik 
pengumpulan data yang digunakan yaitu observasi, wawancara dan dokumentasi. Data yang diperoleh dalam penelitian ini dianalisis melalui proses mereduksi data, penyajian data, dan penarikan kesimpulan (Miles et al., 2014).

\section{HASIL DAN PEMBAHASAN}

Subornisasi perempuan bukan saja dikategorikan sebagai gejala kultural, namun juga merupakan faktor struktural.Pandangan ini didasarkan pada beberapa anggapan bahwa ruang gerak perempuan hanya sebatas urusan domestic dan mengurangi tingkat partisipasi dalam lingkup public, maka status dan martabat perempuan juga ikut ditentukan oleh anggapan yang berkembang hingga saat ini. Pemikiran persoalan perempuan sebagai gejala struktural. Melalui teori ini persoalan gender adalah persoalan yang berkaitan dengan struktur masyarakat dan fungsi atau peran yang dijalankan perempuan dan laki-laki.

Membicarakan masalah perempuan, adalah membicarakan masalah masyarakat atau Berdasarkan hasil penelitian yang dilakukan di Desa Wanio yang berkaitan dengan Perempuan Pengrajin Gerabah, ini membuktikan bahwa peran perempuan sekarang ini mulai berkembang di ranah public, bukan hanya di ranah domestik atau sebatas pekerjaan dirumah saja. Perempuan yang ada di Desa Wanio hampir semua menekuni pekerjaan membuat gerabah.Mengambil peran di dua ranah yaitu di ranah domestik dan ranah publik tentunya terkait dengan bagaimana kehidupan perempuan itu.Yang dimaksud disini yaitu masalah pendidikan, kesehatan dan tempat tinggal yang berkaitan dengan pendapatan yang diperoleh dari pekerjaan yang dijalankannya.

\section{Pendidikan}

Pendidikan perempuan pekerja sebagai pengrajin gerabah yang ada di Desa Wanio masih sangat rendahbahkan ada yang tidak pernah menginjak bangku Sekolah. Ini terbukti dari salah satu informan yang saya wawancara yaitu Ibu Tija yang tidak pernah menginjak bangku sekolah. Waktu dulu memang sekolah belum ada, dan ini yang menjadi penyebab orang-orang terdahulu kurang mengenal pendidikan, tetapi bagusnya walaupun mereka tidak pernah menginjak bangku Sekolah, mereka mampu mengaplikasikan kemampuan-kemampuan yang mereka milihki, sehingga mampu bertahan hidup sampai sekarang.Salah satu pengaplikasian kemampuan mereka yaitu membuat kerajianan tangan yaitu gerabah.

\section{Kesehatan}

Bekerja di dua ranah sekaligus yaitu diranah domestic dan ranah public tidak memepengaruhi kesehatan bagi perempuan yang ada di Desa Wanio yang bekerja sebagai pengrajin gerabah.Membuat gerabah tidak terlalu menguras tenaga hanya sedikit kelelahan ketika terlalu lama duduk. Tidak ada yang beresiko besar terhadap kesehatan Jadi mengenai pekerjaan membuat gerabah oleh perempuan di Desa Wanio, tidak beresiko terhadap kesehatan mereka. Membuat gerabah juga masih dikatakan pekerjaan yang ringan dan tidak terlalu menguras tenaga hanya saja waktu yang terkuras.

\section{Pendapatan}

Membahas mengenai tempat tinggal tidak terlepas dari besarnya pendapatan yang dihasilkan dari membuat gerabah kemudian menjualnya.Gerabah yang dibuat oleh perempuan yang ada di Desa Wanio gerabah yang bahannya dari tanah liat.Masih sangat tradisional.Jadi 


\author{
4 Predestinasi \\ Volume 13, No. 1, Juni 2020 Hal. 1- 6
}

tidak heran jika hasil jual dari gerabah masih sangat rendah. Harga tertinggi dari gerabah yang ada di Desa Wanio ini yaitu Rp20.000-an gerabah yang dijual dengan harga Rp20.000-an hanya gerabah yang mempunyai ukuran besar yaitu gerabah yang dibuat oleh Ibu Tija. Yang digunakan untuk menyimpan air.Dan gerabah dengan harga terendah yaitu gerabah yang hanya laku terjual sebesar Rp.2000 saja.

Berdasarkan hasil penelitian yang saya lakukan di Desa Wanio, terdapat dua pembagian waktu dalam menjalankan pekerjaan di dua ranah sekaligus demi tercapainya keharmonisan dalam keluarga, yakni:

a. Langsung membuat gerabah

Ibu rumah tangga yang sudah tidak mempunyai anak kecil dan suami, mereka biasanya lebih cenderung bangun dan mempersiapkan diri untuk memulai pekerjaan membuat gerabah.Mereka membuat gerabah di dekat rumah mereka masing-masing.Karena di Desa Wanio rata-rata mempunyai rumah panggung jadi mereka menjadikan kolong rumah sebagai tempat membuat gerabah.Mereka yang langsung membuat gerabah biasanya berhenti sejenak sekitar pukul 10.00 untuk mengerjakan pekerjaan rumah seperti memasak, menyapu dan sebagainya.Dan memulai kembali membuat gerabah setelah sholat Dzuhur.Mereka membuat gerabah sampai magrib hanya berhenti disaat waktu ashar untuk sholat kemudian lanjut kembali.

b. Mengerjakan pekerjaan di rumah baru membuat gerabah

Berbeda dari mereka yang tidak mempunyai anak kecil yang harus di urus pagi-pagi, ibu rumah tangga ini harus menyiapkan makanan dan mengurus rumah sebelum membuat gerabah.Waktu mereka membuat gerabah tidak terlalu lama dibanding perempuan yang tidak punya tanggungan yang harus di urus di rumah.

Mereka membuat gerabah setelah suami berangkat kerja, dan anak sudah berangkat ke Sekolah atau yang masih mempunyai anak Balita baru membuat gerabah setelah anaknya sudah bias untuk ditinggalkan entahkah itu dia bermain atau si anak lagi tidur kembali. Dampak yang dirasakan dari perempun pengrajin gerabah yaitu :

\title{
a. Beban kerja
}

Berdasarkan temuan dari hasil penelitian, diperoleh gambaran bahwa pada kasus perempuan cenderung beban kerja meningkat sebagai dampak dari peran-perannya diwilayah pekerjaan publik yang banyak menuntut waktu dan tenaga untuk tugas pekerjaan produktif. hasil penelitian ditemukan adanya kecenderungan pada kasus peremuan beban kerja meningkat sebagaimana konsekuensi dari peran membuat gerabah.Namun, dengan kemampuannya mengadaptasikan diri dengan lingkungan yang dimiliki secara lambat-laun berjalan dengan seimbang antara beban tugas pekerjaan domestik dengan tugas pekerjaan publik sebagai wilayah pekerjaan yang produktif. Demikian apa yang ditemukan dari hasil wawancara dari subjek penelitian sebagaimana yang dituturkan yang intinya mengakui adanya beban pekerjaan pada saat anak mereka bertambah.

b. Kesulitan dalam pekerjaan domestik 
Mereka sedikit kesulitan dalam menjalankan tugas domestiknya karena kurang optimalnya waktu yang dimiliki untuk membagi peran yang dijalankan, seperti waktu bersama suami akan sedikit berkurang dan begitupun dengan anak, anak yang masih kecil yang masih bersekolah. Anak kurang diperhatikan dalam kesehariannya.

\section{SIMPULAN}

Gambaran kehidupan / profil peremuan pengrajin gerabah dapat dilihat dari beberapa aspek. Pertama adalah pendidikan, dimana pendidikan informan penelitian masih tergolong rendah. Kedua adalah kesehatan dimana kondisi kesehatan perempuan pengrajin gerabah yang ada di Desa Wanio dapat dikatakan baik, hanya saja jika membuat gerabah sedikit kelelahan dengan terlalu banyak duduk. Ketiga adalah pendapatan, pendapatan yang mereka terima dari hasil menjual gerabah masih terbilang rendah. Dalam menjalankan dua peran sekaligus perempuan di Desa Wanio, membagi dua macam waktu mereka membuat gerabah. Pertama yaitu langsung membuat gerabah. Kedua yaitu mengerjakan pekerjaan di rumah sebelum membuat gerabah. Adapun dampak dari yang terjadi dalam keluarga pada perempuan mengrajin gerabah di Desa Wanio yaitu, mereka sedikit kesulitan menjalankan tugas domestik karena kurang optimalnya waktu yang dimiliki untuk membagi peran yang dijalankan, kelelahan beraktivitas dalam pekerjaannya, yang mengkibatkan rasa emosi yang kurang stabil muncul karena terlalu kelelahan dalam pekerjaan yang bisa mengganggu kondisi keluarga.

\section{DAFTAR PUSTAKA}

Abu Bakar, A. R., Ahmad, S. Z., Wright, N. S., \& Skoko, H. (2017). The propensity to business startup: Evidence from Global Entrepreneurship Monitor (GEM) data in Saudi Arabia. Journal of Entrepreneurship in Emerging Economies, 9(3), 263-285. https://doi.org/10.1108/JEEE-11-2016-0049

Adil, A., \& Kamal, A. (2016). Impact of Psychological Capital and Authentic Leadership on Work Engagement and Job Related Affective Well-being. Pakistan Journal of Psychological Research, 31(1), 1-21.

Creswell, J. W., \& Creswell, J. D. (2017). Research design: Qualitative, quantitative, and mixed methods approaches. Sage publications.

Daraba, D., Akib, H., Said Saggaf, M., Cahaya, A., \& Salam, R. (2018). Basic public service partnership model based on gender perspective in Makassar City, Indonesia. Journal of Legal, Ethical and Regulatory Issues, 21(4).

Davis, L. S., \& Williamson, C. R. (2019). Does individualism promote gender equality? World Development, 123, 104627. https://doi.org/https://doi.org/10.1016/j.worlddev.2019.104627

Johnson, O. W., Han, J. Y.-C., Knight, A.-L., Mortensen, S., Aung, M. T., Boyland, M., \& Resurrección, B. P. (2020). Intersectionality and energy transitions: A review of gender, social equity and low-carbon energy. Energy Research \& Social Science, 70, 101774. https://doi.org/https://doi.org/10.1016/j.erss.2020.101774 
6 || $\begin{aligned} & \text { Predestinasi } \\ & \text { Volume 13, No. 1, Juni 2020 Hal. 1- } 6\end{aligned}$

Miles, M. B., Huberman, A. M., \& Saldana, J. (2014). Qualitative Data Analysis: A Methods Sourcebook (3 ed.). Sage Publications.

Rohlinger, D. A., Olsen, A., \& Hewitt, L. (2020). Dualing discourse: Democracy, gender equity and discursive politics in rural Morocco. Women's Studies International Forum, 81, 102373. https://doi.org/https://doi.org/10.1016/j.wsif.2020.102373

Rukajat, A. (2018). Pendekatan Penelitian Kualitatif (Qualitative Research Approach). Deepublish.

Turan, M., \& Kara, A. (2018). Online social media usage behavior of entrepreneurs in an emerging market: Reasons, expected benefits and intentions. Journal of Research in Marketing and Entrepreneurship, 20(2), 273-291. https://doi.org/10.1108/JRME-09-20160034

Zhang, J., \& Zhang, Y. (2020). Tourism and gender equality: An Asian perspective. Annals of Tourism Research, 85 , 103067. https://doi.org/https://doi.org/10.1016/j.annals.2020.103067 